\title{
基礎梁主筋を機械式定着したSFRCパイルキャップの耐震性能 SEISMIC PERFORMANCE OF A STEEL FIBER REINFORCED CONCRETE PILE CAP USING HEADED MAIN BARS IN FOUNDATION BEAMS
}

\author{
掛 悟 史 $^{* 1}$, 阪 田 真 規 ${ }^{* 1}$, 田部井 正樹*1, \\ 星野正宏*1, 太田義弘*2, 石川裕次*3 \\ Satoshi KAKE, Masanori SAKATA, Masaki TABEI, \\ Masahiro HOSHINO, Yoshihiro OHTA and Yuji ISHIKAWA
}

\begin{abstract}
In this study, the seismic performance of SFRC pile cap using headed main bars in foundation beams was examined by a lateral loading test and an FEM analysis. A double strut model, involving the development of two struts in the pile cap, was identified as the stress transfer mechanism under lateral loading. The first strut to be formed connects the compressive parts at the opposite foundation beams end sections. The other strut to be formed connects the compressive part at the foundation beam end section to the head anchors of the foundation beam longitudinal bars of the beam end side.
\end{abstract}

Keywords : Pile cap, Steel fiber reinforced concrete, Headed anchor, 3-dimensional non-linear FEM analysis, Stress transfer mechanism パイルキャップ, 鋼䟼維補強コンクリート, 機械式定着具, 3 次元非線形 FEM 解析, 応力伝達機構

\section{1.はじめに}

鉄筋コンクリート（RC）造柱梁接合部に関する研究は, 1950 年 代の坪井らによる研究 ${ }^{1}$ から始まったとされ，その後，国内外で活 発な研究例えば 2)が行われ，柱梁接合部がせん断破壊を起こすという 仮説に基づいた力学モデルが構築された。その結果, 1988 年には鉄 筋コンクリート造建物の終局強度型耐震設計指針・同解説 ${ }^{3)}$ が刊行 され，柱梁接合部の耐震設計が初めて示された。近年は接合部降伏 破壊 ${ }^{4)}$ という新しい概念が提唱され，それらに基づく新たな研究も 盛んに行われている。また地上架構の柱梁接合部に留まらず，柱・ 基礎梁および杭が取りつく基礎架構においても, 近年種々の構造実 験 ${ }^{5), 6)}$ が実施され,パイルキャップを含めた接合部の耐震性能の検討 が行われている。

これら地上架構や基礎架構の接合部の耐震設計の研究が進む一方, $\mathrm{RC}$ 造柱梁接合部の配筋施工性を改善する工法の研究開発は少ない。 特にパイルキャップでは柱主筋, 杭頭鉄筋および 2 方向から通し配 筋される基礎梁主筋, さらにせん断補強筋やかご筋が配筋されるた め, 施工が非常に煩雑になりやすい。加えて, 近年は建設労務者が 不足しており，地上および基礎架構接合部の施工の合理化が強く望 まれている。そこで，筆者らはこれまで実用化が難しかった鋼繊維 補強コンクリート（SFRC：Steel Fiber Reinforced Concrete）を用い, 施工性が良く構造性能にも優れた新しい柱梁接合部構法の提案を行 った ${ }^{7}$ 。提案する SFRC 接合部構法は, 地上架構を対象として梁主
筇を接合部内において機械式定着し，接合部に SFRC を打設するこ とで接合部せん断補強筋の省略を可能とした構法である。提案構法 については，これまでに SFRC十字形接合部を対象とした構造実験 ${ }^{7)}$ および 3 次元非線形 FEM 解析 ${ }^{8}$ を実施し, 接合部での複雑な応力 伝達メカニズムを解明し，接合部の設計式の提案を行ってきた。

本研究は上記の SFRC 接合部構法をパイルキャップに適用した場 合の耐震性能の検討を目的としたものであり，対象は Fig.1 に示す ように基礎梁主筋をパイルキャップ内で機械式定着し，パイルキャ ップに SFRC を打設することでせん断補強筋を省略した架構である。 本架構はパイルキャップ内の配筋施工性の改善に主眼を置いている ため, 設計概念は建築基礎構造設計指針 ${ }^{99}$ の考え方に準拠し，地震

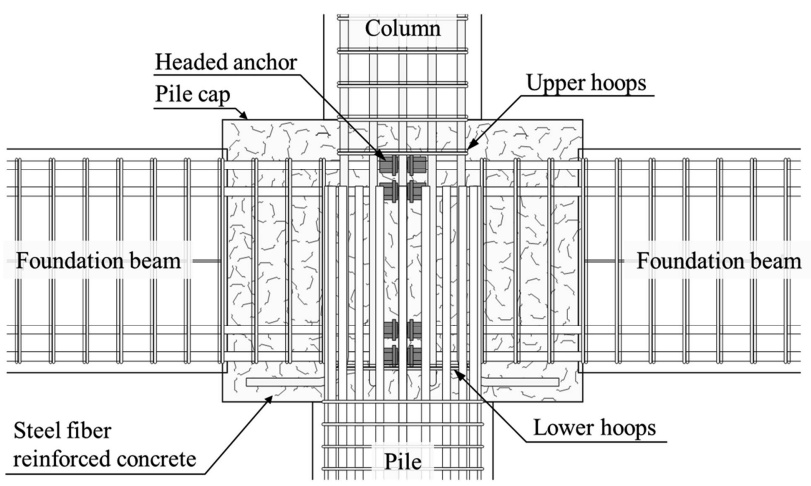

Fig.1 Configuration and bar arrangement of proposed pile cap
*1 (株竹中工務店東京本店設計部

*2 (株) 竹中工務店技術研究所構造部 マネージャー・博士 (工学)

*3 芝浦工業大学システム理工学部 教授・博士 (工学)
Building Design Dept. Tokyo Main Office, Takenaka Corporation

General Manager, Structural Engineering Dept., Research \& Development Institute, Takenaka Corporation, Dr.Eng.

Prof., Shibaura Institute of Technology, Dr.Eng. 
時には基礎梁の柱面位置での曲げ降伏を許容せず弾性限度程度に留 める設計とする。従って, 基礎梁が弾性限度程度までの応力を発揮 したときにパイルキャップを破壊させない保証設計が必要となる。 そのためパイルキャップの破壊時の耐力評価および挙動の把握が重 要となる。そこで本研究は SFRC 接合部構法を適用した場合のパイ ルキャップの終局耐力および破壊モードの検討を行うため構造実験 を実施した。さらに構造実験を実施した試験体に対して 3 次元非線 形 FEM 解析を実施し, 基礎架構の SFRC 接合部内の応力伝達メカニ ズムについて考察した。

\section{SFRC パイルキャップの構造実験}

\section{1 実験概要}

Table1 に試験体諸元を示し, Fig.2 に試験体形状および配筋詳細を 示す。また Table2 および Table3 に試験体に使用したコンクリートお よび鉄筋の材料特性を示す。試験体は杭基礎を想定し柱部材，基礎 梁, 杭部材およびパイルキャップから構成される十字形接合部試験 体 1 体である。試験体は実物の約 $1 / 3$ スケールとした。基礎梁主筋 はパイルキャップ中央で機械式定着しており，定着長さは柱面から $8 d_{b}\left(d_{b}\right.$ : 基礎梁主筋径 $)$ とした。また柱主筋はパイルキャップ内に $35 \mathrm{~d}$ の定着長を確保した $90^{\circ}$ 折曲げ定着とし, 杭頭鉄筋はパイルキ ヤップ内に 30d の直線定着とした。またパイルキャップ内にはせん 断補強筋は配筋されておらず, 基礎梁主筋直上および直下のみ補強 筋（4-D6）を配し，パイルキャップにはSFRCを打設している。試 験体はパイルキャップ内での応力伝達機構を確認するため, 想定破 壊モードを接合部せん断破壊とした。この破壊形式を誘発するため,

Table1 Characteristics of specimen

\begin{tabular}{|c|c|c|}
\hline & Specimen & BJI1 \\
\hline \multicolumn{2}{|c|}{ Assume failure mode } & Shear failure in joint \\
\hline \multirow{4}{*}{ Pile cap } & Section : $B_{j} \times D_{j}[\mathrm{~mm}]$ & $420 \times 800$ \\
\hline & Amount of SF mixed : $\rho_{s}[\%]$ & $1.0 \mathrm{Vol} . \%$ \\
\hline & Hoops & 4-D6（SD785） \\
\hline & $\begin{array}{l}\text { Concrete compressive } \\
\text { strength : }{ }_{j}{ }^{\prime}{ }_{c}\left[\mathrm{~N} / \mathrm{mm}^{2}\right]\end{array}$ & 78.4 \\
\hline \multirow{5}{*}{$\begin{array}{l}\text { Foundation } \\
\text { beams }\end{array}$} & Section : $B_{b} \times D_{b}[\mathrm{~mm}]$ & $270 \times 500$ \\
\hline & Length : $\ell$ ' $[\mathrm{mm}]$ & 2,200 \\
\hline & Longitudinal bars & $\begin{array}{c}6-\mathrm{D} 19 \quad(\mathrm{SD} 590) \\
p_{t}=1.44 \%\end{array}$ \\
\hline & Stirrups & $\begin{array}{c}\text { 4-D6@75（SD785） } \\
p_{w}=0.63 \%\end{array}$ \\
\hline & $\begin{array}{l}\text { Concrete compressive } \\
\text { strength }:{ }_{h} f_{c}^{\prime}\left[\mathrm{N} / \mathrm{mm}^{2}\right]\end{array}$ & 39.6 \\
\hline \multirow{6}{*}{ Column } & Section : $B_{c} \times D_{c}[\mathrm{~mm}]$ & $350 \times 350$ \\
\hline & Hight : $h$ '[mm $]$ & 1840 \\
\hline & Longitudinal bars & $\begin{array}{c}20-\mathrm{D} 16 \quad(\mathrm{SD} 685) \\
p_{g}=2.59 \%\end{array}$ \\
\hline & Hoops & $\begin{array}{c}4-\mathrm{D} 6 @ 75(\mathrm{SD} 785) \\
p_{w}=0.48 \%\end{array}$ \\
\hline & $\begin{array}{l}\text { Concrete compressive } \\
\text { strength }:{ }_{{ }_{f}}{ }^{\prime}\left[\mathrm{N} / \mathrm{mm}^{2}\right]\end{array}$ & 59.3 \\
\hline & Axial force ratio $: \eta$ & 0.20 \\
\hline \multirow{4}{*}{ Pile } & Section $[\mathrm{mm}]$ & $400 \varphi$ \\
\hline & Longitudinal bars & $\begin{array}{c}20-\mathrm{D} 16 \quad(\mathrm{SD} 685) \\
p_{g}=3.16 \%\end{array}$ \\
\hline & Hoops & $\begin{array}{c}2-D 6 @ 50 \quad(\mathrm{SD} 785) \\
p_{w}=0.32 \%\end{array}$ \\
\hline & $\begin{array}{l}\text { Concrete compressive } \\
\text { strength }:{ }_{n} f_{c}\left[\mathrm{~N} / \mathrm{mm}^{2}\right]\end{array}$ & 57.9 \\
\hline
\end{tabular}

基礎梁主筋には SD590 の高強度鉄筋を $p_{t}=1.44 \%$ 配筋し, さらにパイ ルキャップ幅を $420 \mathrm{~mm}$ まで減少させた。併せて, 接合部せん断破 壊時に柱および杭部材で曲げ降伏が発生しないように柱および杭部 材の主筋には SD685 の高強度鉄筋を使用した。パイルキャップに使 用した SFRC は，実験時の圧縮強度は $f_{j}{ }^{\prime}{ }^{\prime}=78.4 \mathrm{~N} / \mathrm{mm}^{2}$ であった。ま
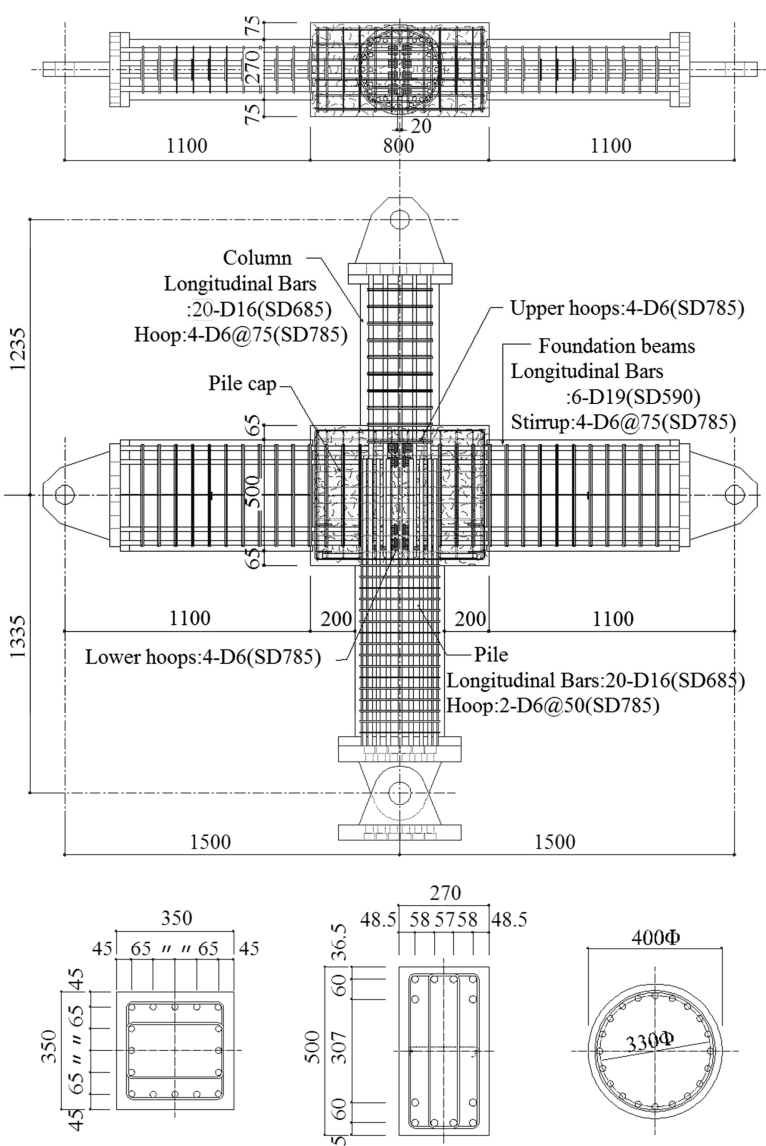

$\underline{\text { Column }}$
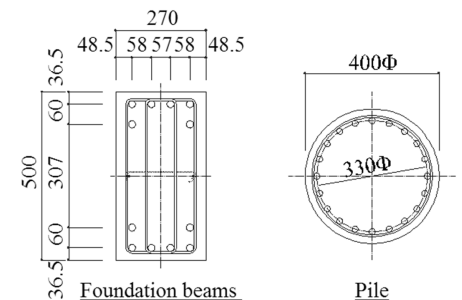

Pile

Fig.2 Configurations and bar arrangement of specimen

Table2 Properties of concrete material

\begin{tabular}{|c|c|c|c|c|}
\hline Members & $\begin{array}{c}f^{\prime}{ }_{c} \\
{\left[\mathrm{~N} / \mathrm{mm}^{2}\right]}\end{array}$ & $\begin{array}{c}\varepsilon_{B} \\
{\left[\times 10^{-6}\right]}\end{array}$ & $\begin{array}{c}E_{c} \\
{\left[\mathrm{~N} / \mathrm{mm}^{2}\right]}\end{array}$ & $\begin{array}{c}\sigma_{s p} \\
{\left[\mathrm{~N} / \mathrm{mm}^{2}\right]}\end{array}$ \\
\hline Pile cap (SFRC) & 78.4 & 2896 & $3.83 \times 10^{4}$ & 5.06 \\
\hline Foundation beam & 39.6 & 2108 & $2.91 \times 10^{4}$ & 3.58 \\
\hline column & 59.3 & 2675 & $3.38 \times 10^{4}$ & 3.80 \\
\hline pile & 57.9 & 2518 & $3.42 \times 10^{4}$ & 4.41 \\
\hline \multicolumn{5}{r}{$f_{c}^{\prime}:$ Compressive strength, $\varepsilon_{B}:$ Compressive strength strain } \\
$E_{c}$ : Elastic modulus, $\sigma_{s p}:$ Splitting strength
\end{tabular}

Table3 Properties of steel material

\begin{tabular}{|c|c|c|c|c|}
\hline Grade & $\begin{array}{c}\sigma_{y} \\
{\left[\mathrm{~N} / \mathrm{mm}^{2}\right]}\end{array}$ & $\begin{array}{c}E_{s} \\
{\left[\mathrm{~N} / \mathrm{mm}^{2}\right]}\end{array}$ & $\begin{array}{c}\sigma_{u} \\
{\left[\mathrm{~N} / \mathrm{mm}^{2}\right]}\end{array}$ & Members \\
\hline $\begin{array}{c}\text { D19 } \\
(\mathrm{SD} 590)\end{array}$ & 612 & $1.89 \times 10^{5}$ & 767 & $\begin{array}{c}\text { Foundation beam } \\
\text { longitudinal bars }\end{array}$ \\
$\begin{array}{c}\text { D16 } \\
\text { (SD685) }\end{array}$ & $831^{*}$ & $1.94 \times 10^{5}$ & 1067 & $\begin{array}{c}\text { Column and Pile } \\
\text { longitudinal bars }\end{array}$ \\
\hline $\begin{array}{c}\text { D6 } \\
\text { (SD785) }\end{array}$ & $925^{*}$ & $1.92 \times 10^{5}$ & 1066 & Hoops and Stirrups \\
\hline \multicolumn{5}{|c|}{$\sigma_{y}:$ yield strength, $E_{s}:$ Elastic modulus, $\begin{array}{c}\sigma_{u}: \text { Tensile strength } \\
* 0.2 \% \text { offset strength }\end{array}$}
\end{tabular}
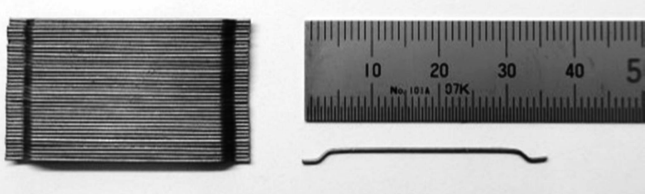

Photo1 Shape of steel fiber 
た鋼繊維はPhoto1 に示寸繊維径 $0.55 \mathrm{~mm}$, 繊維長さ $35 \mathrm{~mm}$, アスペ クト比 65 , 引張強度 $1,550 \mathrm{~N} / \mathrm{mm}^{2}$ 以上の両端フック付きのものを使 用し, 鋼繊維混入量は現場施工が可能な混入量であるコンクリート 体積比 $1.0 \mathrm{Vol} . \%$ とした。

試験体の製作は以下の手順で行った。最初に杭部材および基礎梁 部材を先行して製作し, 杭部材を設置後, 柱主筋および基礎梁主筋 直下補強筋を配筋し, 基礎梁部材を落とし込んだ。その後, 基礎梁 主筋直上補強筋を配筋し, パイルキャップに SFRCを打設した。最 後に, 柱部材の配筋・型枠作業を行い, コンクリート打設を行った。

\section{2 載荷方法}

Fig. 3 に載荷装置を示す。柱, 基礎梁および杭部材端部にピン支承 を設置し, 試験体上部の鈆直ジャッキを用いて柱軸力比 $\eta=0.20$ $\left(\eta=N / B_{c} D_{c} \cdot f^{\prime}{ }_{c}^{\prime}, N\right.$ : 軸力, $B_{c}$ : 柱幅, $D_{c}$ : 柱せい, ${ }_{c} f^{{ }^{\prime}}{ }_{c}$ : 柱部材コン クリート強度）に相当する軸力を導入した。軸力導入後, 柱部材の 先端の水平変位が 0 となるように水平ジャッキを制御しながら, 基 礎梁左右端部の鉛直ジャッキにより基礎梁に逆対称モーメントが作 用するように正負漸増繰り返し載荷を行った。梁端加力は変位漸増 繰り返し載荷とし, Fig.4に示すように層間変形角 $R= \pm 1.0, \pm 2.0, \pm 3.3$, $\pm 5.0,( \pm 2.0), \pm 7.5, \pm 10,( \pm 5.0), \pm 15, \pm 20, \pm 30, \pm 40$ および $\pm 50 \times 10^{-3} \mathrm{rad}$

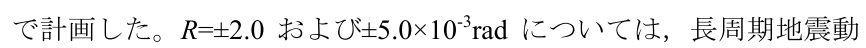
を考慮した 10 回の多数回繰り返し載荷を行い，（）内のサイクルは 履歴特性を把握するために各変形後の小サイクルを想定した。また, パイルキャップの変形については試験体裏面に画像相関法による光 学式全視野 3 次元変位・ひずみ計測システム ${ }^{10)}$ を使用し, パイルキ ヤップのコンクリート面のひずみを測定した。

\section{3. 実験結果}

\section{1 損傷状況}

Photo 2 に層間変形角 $R=5.0,10 \times 10^{-3} \mathrm{rad}$ および実験終了時の試験体

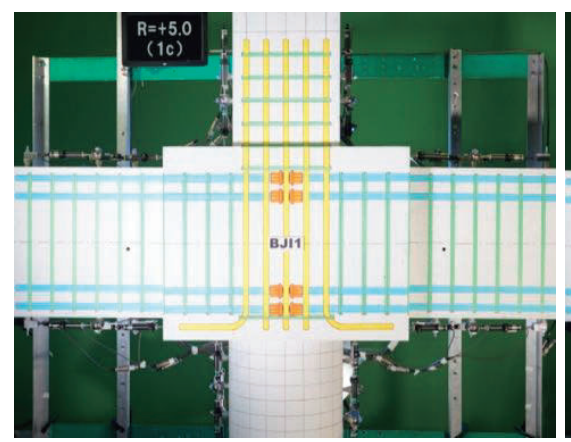

(a) $R=5.0 \times 10^{-3} \mathrm{rad}$

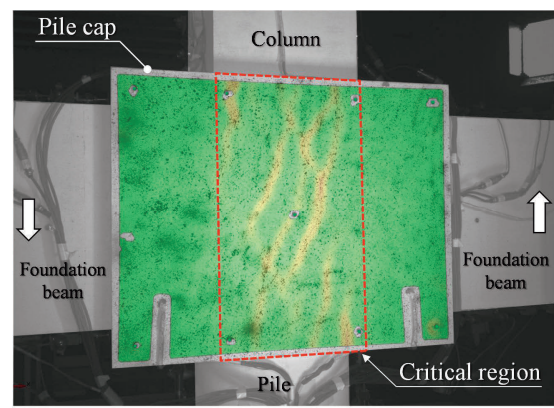

(a) $R=5.0 \times 10^{-3} \mathrm{rad}$
の損傷状況を示し, Fig.5 に画像相関法により算出した層間変形角 $R=5.0,10$ および $20 \times 10^{-3} \mathrm{rad}$ 時のパイルキャップ裏面における最大 主ひずみ分布を示す。 $R=1.0 \times 10^{-3} \mathrm{rad}$ の載荷サイクルにおいて基礎梁

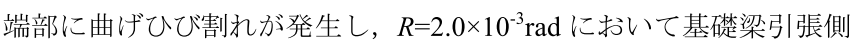

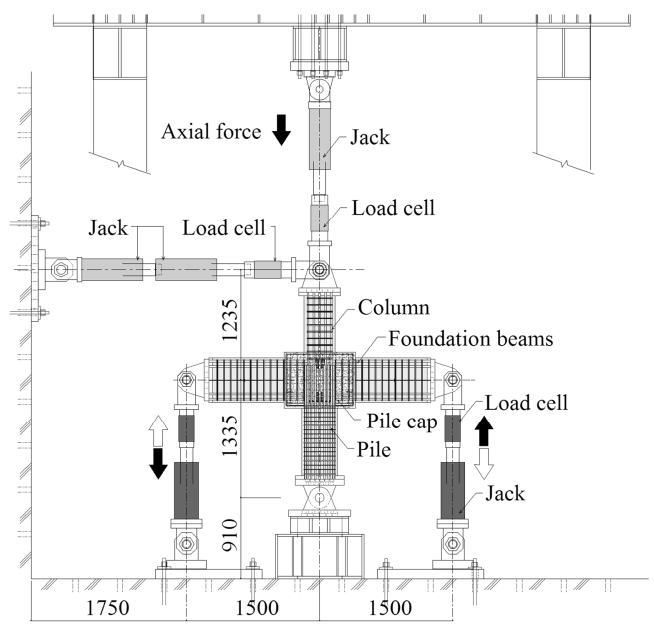

Fig.3 Loading system

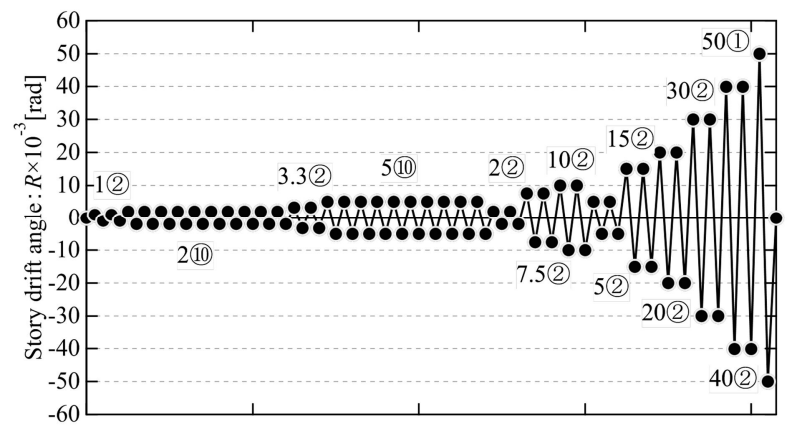

(1), (2), (10): Number of loading cycle Fig.4 Loading course

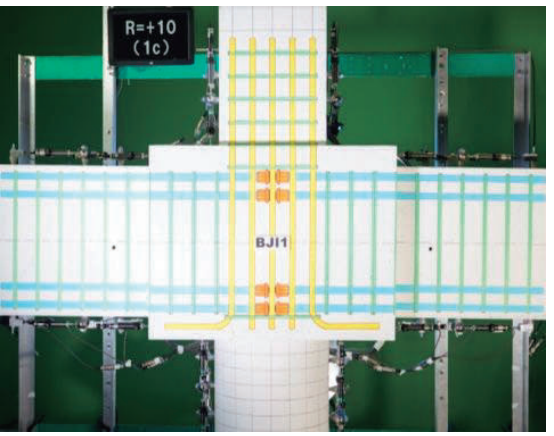

(b) $R=10 \times 10^{-3} \mathrm{rad}$

Photo2 Damage of specimen

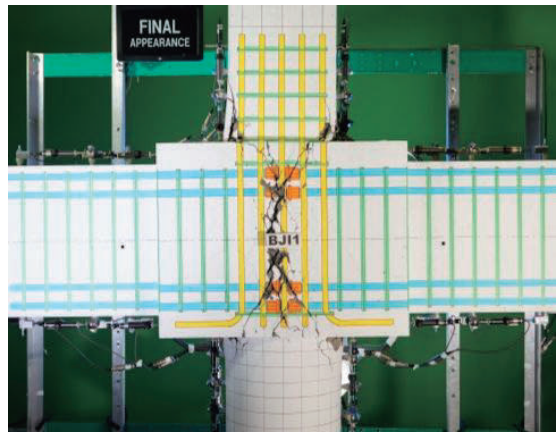

(c) After the test

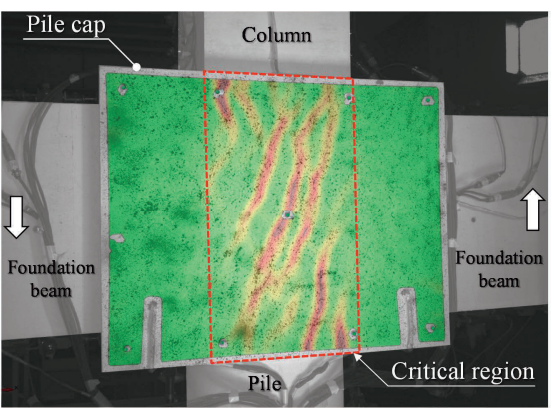

(b) $R=10 \times 10^{-3} \mathrm{rad}$

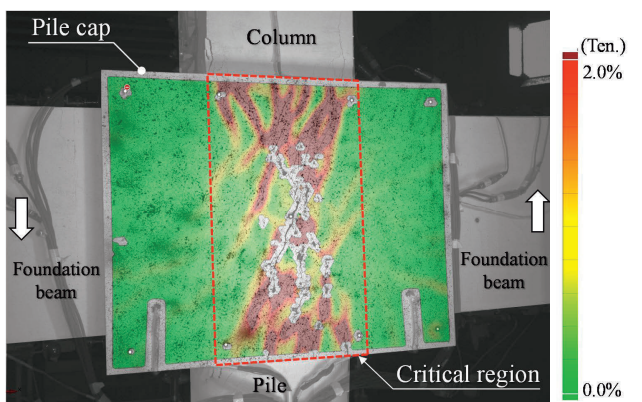

(c) $R=20 \times 10^{-3} \mathrm{rad}$
Fig.5 Distribution of maximum principal strain 
主筋に取り付けた機械式定着具を起点として, 柱部材とパイルキャ ップの入隅部または杭部材とパイルキャップの入隅部に向かう線上 に斜めひび割れが発生した。その後, $R=3.3 \times 10^{-3} \mathrm{rad}$ の載荷サイクル では柱脚部および杭頭部に曲げひび割れが発生し， $R=5.0 \times 10^{-3} \mathrm{rad}$ で はパイルキャップの柱面および杭面位置において曲げひび割れが発

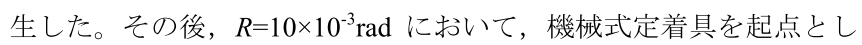
て柱部材および杭部材内に入り込む 45 度方向の斜めひび割れが発 生した。その後はパイルキャップ中央部の斜めひび割れ本数・ひび 割れ幅の増加が顕著となり, 耐力が低下したため実験を終了した。

また Fig.5 より画像相関法での最大主ひずみにおいても各載荷サ イクルにおいて上記のひび割れ発生箇所のひずみが大きくなる傾向 を示した。パイルキャップの最大主ひずみが増加する箇所はパイル キャップの柱面・杭面に囲われた範囲（Fig.5 赤点線内）に集中して おり，柱面・杭面より外側においてはほとんどひずみが生じていな い。そして実験における損傷もこの領域に集中している。以上のこ とからパイルキャップでは，パイルキャップの上端，下端，柱面・ 杭面に囲われた範囲を接合部パネルとして応力伝達を行っていると 推察される。

\section{2 復元力特性}

Fig.6 に柱せん断力および等価粘性減衰定数一層間変形角関係を 示し, 図中には各種ひび割れ点および鉄筋降伏点を示す。実験では, 基礎梁曲げひび割れ，パイルキャップの斜めひび割れが発生すると 共に接線剛性が緩やかに低下し， $R=-10 \times 10^{-3} \mathrm{rad}$ および $15 \times 10^{-3} \mathrm{rad}$ に おいてパイルキャップ内に配筋した基礎梁主筋直上および直下補強 筋の引張降伏が発生した。その後, 正負載荷共に $R=15 \times 10^{-3} \mathrm{rad}$ にお いて最大耐力を記録し，その後はパイルキャップの斜めひび割れの 伸展に伴い耐力が緩やかに低下し, 実験を終了した。実験終了時ま で各部材の主筋の引張降伏は発生せず, 逆 $\mathrm{S}$ 字形のエネルギー吸収 能の小さい履歴形状を示した。また等価粘性減衰定数も $R=10 \times 10^{-3} \mathrm{rad}$ 以前では $h_{e q}=2 \sim 4 \%$ 程度に分布しており, それ以降は 層間変形角の増加とともに $h_{e q}=10 \%$ 程度まで増加した。

\section{3 せん断補強筋応力度}

Fig.7 に基礎梁主筋直上および直下補強筋を含む柱および杭部材 のせん断補強筋の各変形角正側載荷ピーク時における応力度分布を 示す。鉄筋の応力度は鉄筋の履歴特性をバイリニアと仮定し，鉄筋 に貼付したひずみゲージ（Fig.7 参照）の值より算定した。Fig.7 よ り，パイルキャップ中央部に機械式定着具を起点とした斜めひび割 れが発生した $R=3.3 \times 10^{-3} \mathrm{rad}$ 以降, せん断補強笳の忘力が発現した。 またせん断補強筋の応力分布については, 機械式定着具を起点とし た 45 度の線に交わる補強筋では部材角の増加に伴い応力も増加寸 る傾向を示しており, 基礎梁主筋直上および直下補強筋の応力が最 も大きくなる傾向を示した。その後, 試験体が最大耐力を記録した $R=15 \times 10^{-3} \mathrm{rad}$ では基礎梁主筋直上および直下補強筋において引張降 伏が発生した。

\section{4 基礎梁主筋応力度}

Fig. 8 に基礎梁上端 1 段筋の各変形角正側載荷ピーク時におりる応 力度分布を示寸。鉄筋の応力度はせん断補強筋同様, 鉄筋の履歴特 性をバイリニアと仮定し, 鉄筋に貼付したひずみゲージ (Fig.8 参照) の值より算定した。Fig.8 より, 基礎梁端部（断面 A）では基礎梁端 部に曲げひび割れが発生した $R=1.0 \times 10^{-3} \mathrm{rad} よ り$ 忘が作用してお

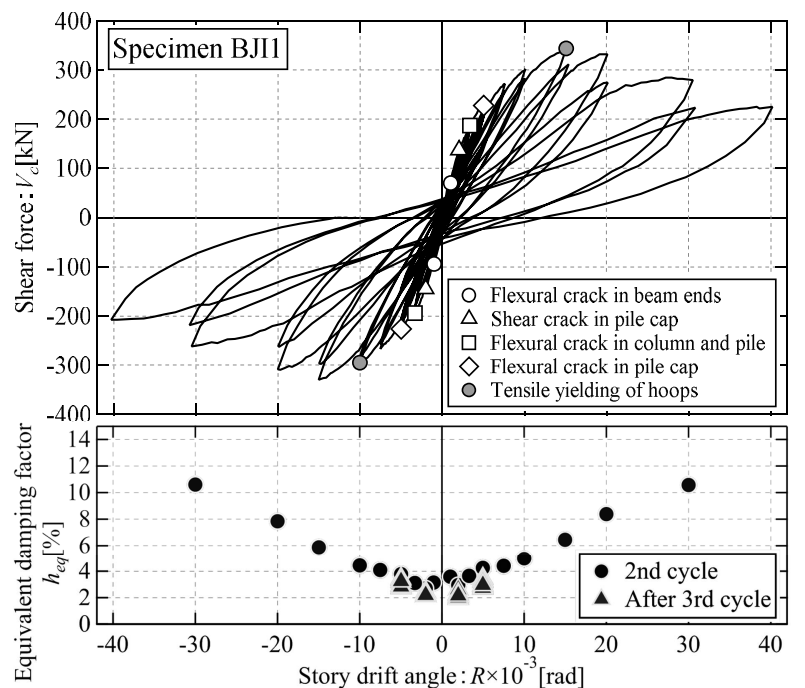

Fig.6 Shear force - story drift angle response and major events
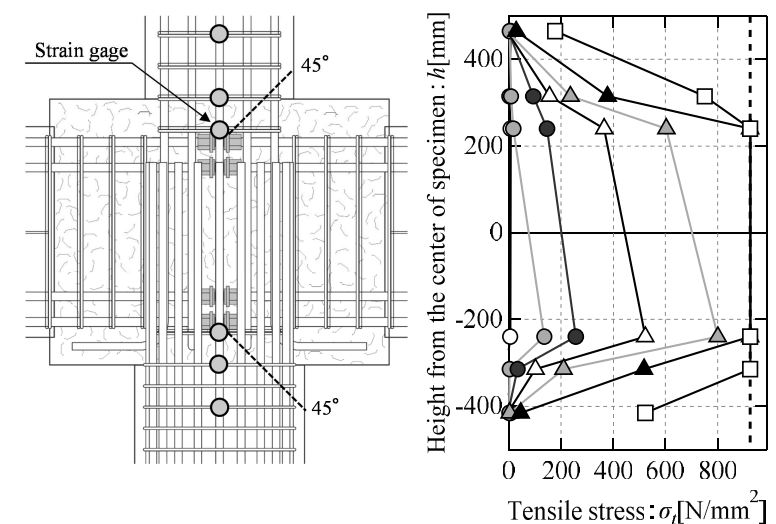

$-O-R=2.0 \times 10^{-3} \mathrm{rad}-O R=3.3 \times 10^{-3} \mathrm{rad}-\mathrm{O} R=5.0 \times 10^{-3} \mathrm{rad} \triangle-R=7.5 \times 10^{-3} \mathrm{rad}$ $\triangle R=10 \times 10^{-3} \mathrm{rad} \rightarrow R=15 \times 10^{-3} \mathrm{rad} \quad \square-R=40 \times 10^{-3} \mathrm{rad} \quad \cdots$ Yield strength: $\sigma_{y}$

Fig.7 Stress distribution of hoops
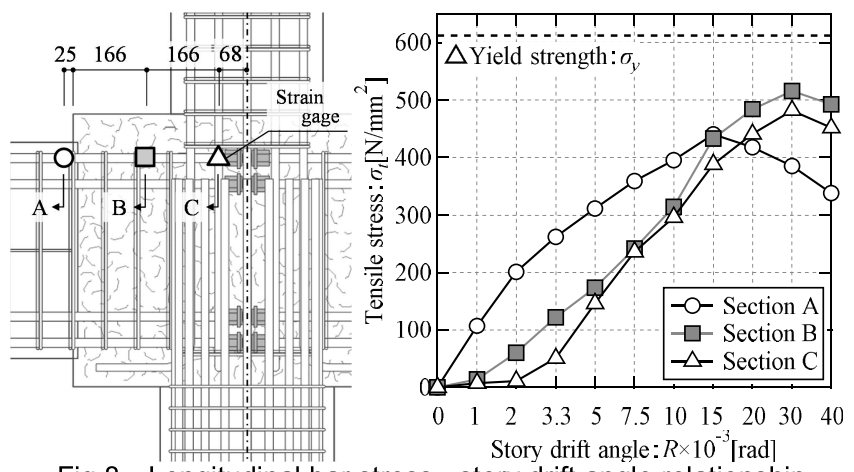

Fig.8 Longitudinal bar stress - story drift angle relationship

り, パイルキャップに斜めひび割れが発生した $R=3.3 \times 10^{-3} \mathrm{rad}$ 以降は 応力の増加が緩やかとなった。その後, 基礎梁主筋直上および直下 補強筋の引張降伏が発生した $R=15 \times 10^{-3} \mathrm{rad}$ 以降については鉄筋の応 力が減少した。断面 C の機械式定着具際では，パイルキャップに斜 めひび割れが確認された $R=3.3 \times 10^{-3} \mathrm{rad}$ において応力が作用し始め, 基礎梁主筋直上および直下補強筋が引張降伏した $R=15 \times 10^{-3} \mathrm{rad}$ 以降 については応力の増加が緩やかとなった。

\section{5 最大耐力の評価方法}

実験では，パイルキャップに発生した斜めひび割れが大きく伸展 
し最終破壊に至った。そこで本節では接合部せん断破壊および基礎 梁主筋による搔き出し定着破壊の耐力算定式により最大耐力の評価 を行う。BJI1 試験体のように梁主筋が接合部内で機械式定着されて いる接合部のせん断強度算定式は文献 7)を参考に（1）式で求める。

(1) 式は Fig.9 に示すように基礎梁の引張側主筋に取りついた機械 式定着具から圧縮縁を結ぶ圧縮ストラット 1 と, 両基礎梁端部の圧 縮縁同士を結ぶ圧縮ストラット 2 の 2 つのストラットが接合部に形 成されるとし， 2 つのストラットが集約した点の応力度が有効圧縮 強度 $\sigma_{d}$ に達したときの耐力を算定する。せん断強度算定時に使用す る接合部有効幅 $b_{s}$ については Fig.10 に示寸幅を採用した。なお，本 試験体では梁幅（パイルキャップ幅）が柱幅よりも大きいため， $b_{b}$ は柱幅を用いた。(1) 式の詳細については文献 7)を参照されたい。 分割ストラット接合部のせん断強度 : $\boldsymbol{V}_{\boldsymbol{j} \boldsymbol{u}}{ }^{7}$

$$
\begin{aligned}
& V_{j u}=\min \left(T_{s}, \quad \phi D_{1} \cdot \cos \theta_{1}\right)+\phi D_{2} \cdot \cos \theta_{2} \\
& D_{1}=\sigma_{d} \cdot A_{s t r l} \quad D_{2}=\sigma_{d} \cdot A_{s t r 2} \\
& A_{s t r l}=a_{s l} \cdot b_{s} \quad A_{s t r 2}=a_{s 2} \cdot b_{s} \\
& T_{s}=0.7 A_{w} \cdot \sigma_{w y}+\sum A_{c} \cdot \sigma_{y} / \sqrt{3}
\end{aligned}
$$

$\phi$ : 耐力低減係数 $(=0.85)$

$A_{s t r 1}, A_{s t r 2} \quad$ : ストラット 1 およびストラット 2 の面積 $\left[\mathrm{mm}^{2}\right]$

$b_{s}$ : 接合部の有効幅 $\left(=b_{b}+b_{a 1}+b_{a 2}, \quad\right.$ Fig.10 参照 $)$

$b_{b} \quad:$ 柱幅 $[\mathrm{mm}]$

$b_{a 1}, b_{a 2} \quad: b_{i} / 2$ または $D / 4$ の小さい方

$b_{i} \quad$ : 柱両側面からこれに平行するパイルキャップ側面まで の長さ $[\mathrm{mm}]$

$D \quad$ : 柱せい $[\mathrm{mm}]$

$A_{w} \quad:$ 直上および直下補強筋総断面積 $\left[\mathrm{mm}^{2}\right]$

$\sigma_{w y}:$ 直上および直下補強筋降伏点 $\left[\mathrm{N} / \mathrm{mm}^{2}\right]$

$A_{c} \quad:$ 引張側の柱主筋断面積 $\left[\mathrm{mm}^{2}\right]$

$\sigma_{y} \quad:$ 柱主筋降伏点 $\left[\mathrm{N} / \mathrm{mm}^{2}\right]$

ストラット 1, ストラット 2 の形状寸法

$$
\begin{aligned}
& a_{s 1}=a_{s} \cdot \frac{\tau_{1 \max }}{\tau_{1 \max }+\tau_{2 \max }}, a_{s 2}=a_{s} \cdot \frac{\tau_{2 \max }}{\tau_{1 \max }+\tau_{2 \max }} \\
& a_{s}=\sqrt{a_{b}^{2}+a_{c}^{2}} \\
& a_{c}=0.25 h_{c}, a_{b}=0.25 h_{b}
\end{aligned}
$$

$a_{s 1}, a_{s 2} \quad$ : ストラット 1 およびストラット 2 のせい $[\mathrm{mm}]$

$a_{s} \quad: 2$ 個のストラットのせいの和 $[\mathrm{mm}]$

$a_{c}, a_{b}:$ 柱および梁の圧縮域深さ $[\mathrm{mm}]$

$h_{c}, h_{b} \quad:$ 柱せいおよび梁せい $[\mathrm{mm}]$

ストラット 1 およびストラット $\mathbf{2}$ が負担する接合部せん断応力度

$$
\begin{aligned}
& \tau_{1 \max }=\frac{\sigma_{d}}{2} \sin 2 \theta_{1}, \quad \tau_{2 \max }=\frac{\sigma_{d}}{2} \sin 2 \theta_{2} \\
& \sigma_{d}=\alpha_{s f} \cdot v \cdot{ }_{j} f^{\prime}{ }_{c} \\
& v=0.461 \cdot 3.68_{j} f^{\prime}{ }^{-0.333}
\end{aligned}
$$

$\alpha_{s f} \quad:$ SFRC 強度係数（1.0 Vol. \%のとき $\alpha_{s f}=1.5 ）$

${ }_{i} f^{\prime} c \quad$ : パイルキャップのコンクリート圧縮強度 $\left[\mathrm{N} / \mathrm{mm}^{2}\right]$

$$
\theta_{1}=\tan ^{-1}\left(\frac{h_{b}^{\prime \prime}}{h_{c a}^{\prime \prime}}\right), \quad \theta_{2}=\tan ^{-1}\left(\frac{h_{b}^{\prime \prime}}{h_{c}^{\prime \prime}}\right)
$$

$\theta_{1}, \theta_{2} \quad$ : ストラット 1 およびストラット 2 の角度

$h_{b}{ }^{\prime}$ : 梁最外縁主筋間距離 $[\mathrm{mm}]$ $h_{c a} ” ：$ 柱主筋から機械式定着具支圧面までの距離 $[\mathrm{mm}]$

$h_{c}{ }^{\prime} \quad$ : 柱最外縁主筋間距離 $[\mathrm{mm}]$

また掻き出し定着耐力については，Fig.11 に示すように機械式定 着具を起点として圧縮応力ブロックが生じる側の柱および杭部材と パイルキャップの入隅部に向から破壊面 1 と, 機械式定着具を起点 として接合部外の柱部材および杭部材内 45 度方向へ向から破壊面 2 の 2 つの破壊面を想定した。そこで勒性保証型耐震設計指針 ${ }^{11)}$ の掻 き出し定着耐力の算定式を参考に, 想定破壞面における SFRC パイ ルキャップでの掻き出し定着強度算定式を誘導し式（9）に示す。掻 き出し定着耐力 $F_{u s}$ はコンクリート負担分およびせん断補強筋負担 分から算定でき，コンクリート負担分は想定破壊面 1 と想定破壊面 2 による負担分から求める。両想定破壊面ともに SFRC 内の掻き出 し破壊となり，鋼䋊維の架橋効果によって定着耐力が増加すること を考慮して, 文献 7）より SFRC 強度係数 $\alpha_{s f}$ を引用した。さらに文 献 7）より，機械式定着した鉄筋の引抜き試験で，掻き出し定着耐 力が勒性保証型耐震設計指針 ${ }^{10)}$ の掻き出し定着耐力計算值より低下 することが報告されているため，コンクリート負担分低減係数 $\alpha_{c}=0.70$ を引用した。なお, 想定破壊面 1 において杭部材とパイルキ

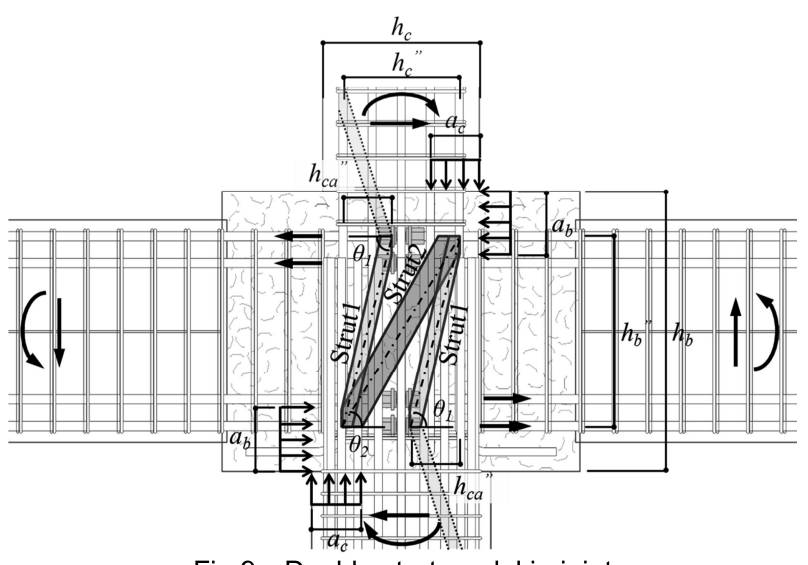

Fig.9 Double strut model in joint

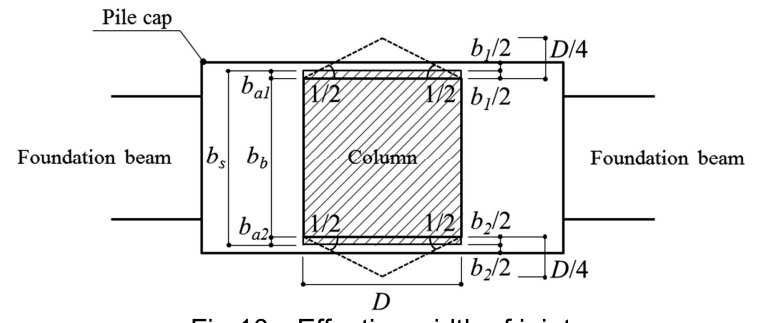

Fig.10 Effective width of joint

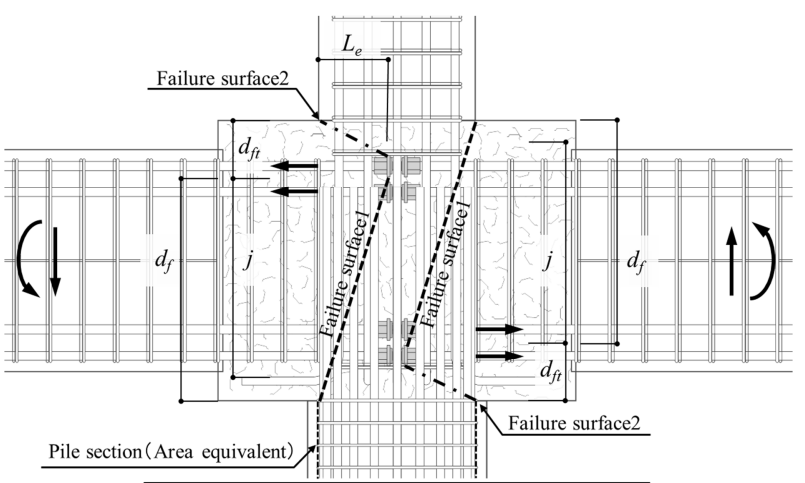

---- Failure surface $1 \quad$-.- Failure surface 2

Fig.11 Anchorage failure surface of joint 
Table4 Ultimate strength of BJl1 (calculated and experimental values)

\begin{tabular}{|c|c|c|c|c|c|c|c|c|c|}
\hline \multicolumn{3}{|c|}{ Experimental value $: Q_{\text {exp }}[\mathrm{kN}]$} & \multicolumn{3}{c|}{ Calculated value $: Q_{c a}[\mathrm{kN}]$} & \multicolumn{3}{c|}{$Q_{\text {exp }} / \min \left\{V_{j u}, Q_{T}, Q_{m u}\right\}$} \\
\hline Positive loading & Negative loading & Average & $V_{j u}{ }^{*}{ }^{*}$ & $Q_{T}{ }^{* 2}$ & $Q_{m u}$ & Positive loading & Negative loading & Average \\
\hline 344.5 & -329.6 & 337.1 & 306.2 & 324.2 & 463.7 & 1.13 & 1.08 & 1.10 \\
\hline
\end{tabular}

*1 Calculated ultimate shear strength in joint based on formula (1)

*2 Calculated anchorage failure strength in joint based on formula (9)

*3 Calculated ultimate flexural strength based on AIJ formula

ヤップの入隅部は杭部材が円形断面で曲線状となっており, 入隅部 の定義が煩雑であるため, 本論では杭断面を面積等価な正方形断面 に置換し，この正方形断面とパイルキャップの入隅部と機械式定着 具を結ぶ線上に破壊面が発生するとした。また想定破壊面 2 におい ては安全側の配慮および設計式の簡略化を図るため, 機械式定着具 を起点とした 45 度方向の破壊面を柱部材および杭部材とパイルキ ヤップの入隅部に向から破壊面一修正した。

\section{择き出し定着耐力 : $\boldsymbol{F}_{\text {us }}$}

$$
F_{u s}=k_{n} \cdot\left(T_{c}+T_{w}\right)
$$

$k_{n}$ ：柱軸力による補正係数（但し, $k_{n} \leqq 1+0.0016_{j} f^{\prime}{ }_{c}$ ） $\left[\mathrm{kgf} / \mathrm{cm}^{2}\right]$

$$
k_{n}=1+\sqrt{\sigma_{o} / f_{j} f_{c}^{\prime}}
$$

$\sigma_{0} \quad:$ 柱軸応力度 $\left[\mathrm{N} / \mathrm{mm}^{2}\right]$

$T_{c}$ : 掻き出し定着耐力のうちコンクリート負担分 $[\mathrm{N}]$

$$
T_{c}=T_{c 1}+T_{c 2}
$$

$T_{c 1}$ : 想定破壊面 1 におけるコンクリート負担分 $[\mathrm{N}]$

$$
T_{c 1}=\frac{\alpha_{c} \cdot \alpha_{s f} \cdot L_{e} \cdot b_{e} \sqrt{L_{e}{ }^{2}+j^{2}}}{j} 0.313 \sqrt{f_{j} f^{\prime}}
$$

$T_{c 2}$ ：想定破壊面 2 におけるコンクリート負担分 $[\mathrm{N}]$

$$
T_{c 2}=\frac{\alpha_{c} \cdot \alpha_{s f} \cdot L_{e} \cdot b_{e} \sqrt{L_{e}^{2}+d_{f t}^{2}}}{d_{f t}} 0.313 \sqrt{j f_{c}^{\prime}}
$$

$\alpha_{c} \quad$ : コンクリート負担分低減係数 $(=0.70)$

$L_{e} \quad$ : 柱面からの基礎梁主筋定着長さ $[\mathrm{mm}]$

$b_{e} \quad$ : 柱有効幅 $\left(=b+C_{e l}+C_{e 2}\right) \quad[\mathrm{mm}]$

$b$ : 左右最外縁基礎梁主筋幅 $[\mathrm{mm}]$

$C_{e l}, C_{e 2} \quad:$ パイルキャップ側面から左右最外縁基礎梁主筋芯

$$
\text { までの最短距離 }\left(C_{e l}, C_{e 2} \leqq 0.8 L_{e}\right)[\mathrm{mm}]
$$

$j \quad$ : 柱面および杭面における基礎梁応力中心間距離 $[\mathrm{mm}]$

$d_{f}$ : フーチング縁から基礎梁主筋重心位置までの距離 $[\mathrm{mm}]$

$d_{f t}$ : 基礎梁引張側主筋重心位置からパイルキャップ引張縁 までの距離 $[\mathrm{mm}]$

$T_{w}$ : 择き出し定着耐力のうちせん断補強筋負担分 $[\mathrm{N}]$

$$
T_{w}=0.7 A_{w} \cdot \sigma_{w y}
$$

Table4 に（1）式および（9）式より算出したパイルキャップのせ 几断強度および搔き出し定着破壊時の柱せん断力計算值 $V_{j u}$ および $Q_{T}$ と, 実験で得られた最大耐力 $Q_{\text {exp }}$ との比較を示す。Table4 には $\mathrm{RC}$ 規準 ${ }^{12)}$ に基づき基礎梁主筋が基礎梁端部で曲げ降伏した時の曲 げ終局強度計算值 $Q_{m u}$ も併せて示す。Table 4 より, 試験体の耐力計 算值は分割ストラットモデルによる接合部せん断強度で決定してお り，計算值により実験值を $1.08 〜 1.13$ 倍と安全側かつ精度良く評価 できることを確認し，かつ破壊モードの判定も行うことができた。

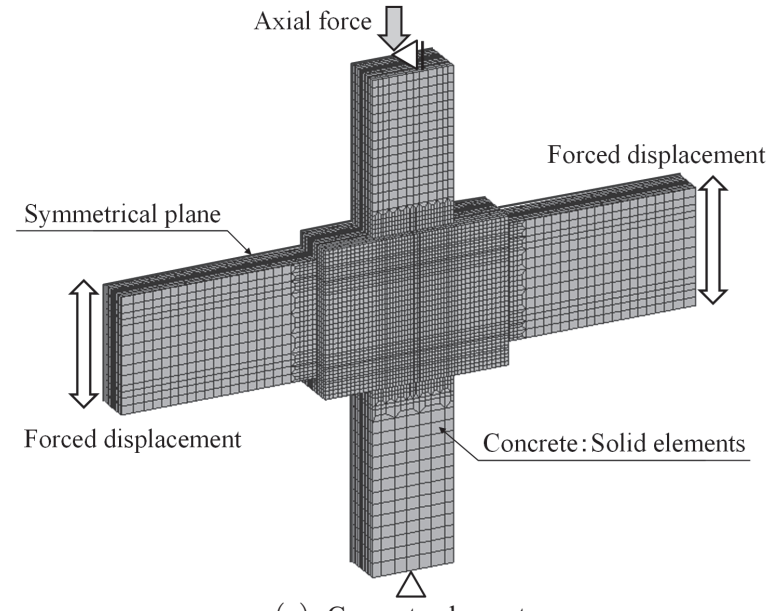

(a) Concrete elements

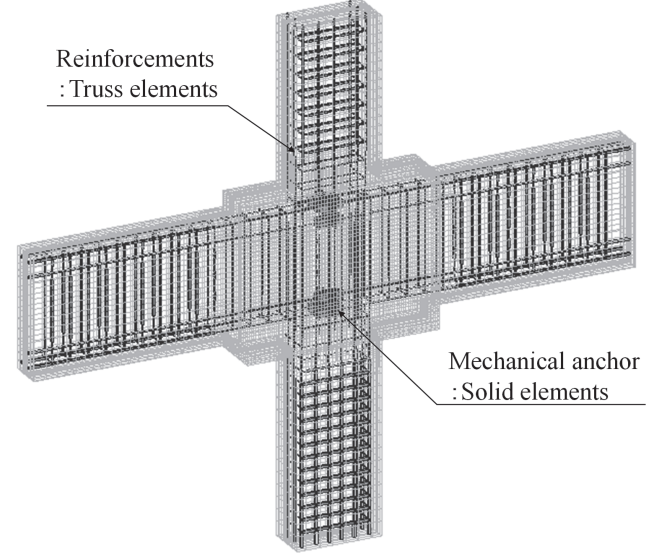

(b) Reinforcement and mechanical anchor elements Fig.12 Mesh - division of FEM analysis

\section{3 次元非線形 FEM 解析による応力伝達機構の検討}

\section{1 FEM 解析の概要}

Fig.12に解析モデルの要素分割図を示す。解析は BJI1 試験体につ いて行い，解析モデルは試験体の対称性を考慮して奥行方向に対し て $1 / 2$ モデルとした。また杭部材のモデル化にあたっては曲げ耐力 が同等となるように杭断面を面積等価な正方形断面に置換し，主筋 とせん断補強筋を断面積および主筋数をそれぞれ等しく, かつ, 各 辺の主筋数が同一となるようにモデル化を行った。基礎梁，柱およ び杭部材は主筋・せん断補強筋の配置位置に対応するように分割し, 接合部は機械式定着具の配置位置も考慮し分割を行った。なお，本 解析モデルでは，はかま筋はモデル化していない。

加力は実験と同様の境界条件を与え, 柱軸力 $\eta=0.20$ 相当の軸力を 試験体上部に導入後, 左右の梁端部に実験と同様の層間変形角とな るよう強制変位を与えた。本研究での解析には野口らのコンクリー 卜構成則 ${ }^{13)}$ を組み込んだ自社開発の 3 次元非線形 RC 解析プログラ ムを用いた。 
(1) コンクリートモデル

コンクリートは 8 節点アイソパラメトリック立体要素でモデル化 した。応力ーひずみ関係については，圧縮側上昇域は Saenz 式 ${ }^{14)}$, 圧縮軟化域は直線とし, 基礎梁, 柱および杭部材についてはコアコ ンクリートとカバーコンクリートを異なる材料構成則により定義し た。コアコンクリートのせん断補強筋による拘束効果については, 修正 Kent\&Park モデル ${ }^{15}$ により定め, カバーコンクリートでは拘束 効果を考慮せず，一軸圧縮強度まで到達すると仮定した。パイルキ ヤップの SFRC については, せん断補強筋を配筋していないことか ら，拘束効果は考慮せず一軸圧縮強度まで到達すると仮定した。

また引張側については，ひび割れ発生点までは線形で，ひび割れ 後のテンションスティフニング特性は出雲らのモデル ${ }^{16)}$ を適用し, 普通コンクリートを使用した基礎梁，柱および杭部材については係 数 $c$ を $c=1.00$ とした。パイルキャップで使用した SFRCについて文 献 8）では，Fig.13（a）に示寸ように引張力作用方向（鋼繊維の架 橋効果により引張応力を発揮する方向）とひび割れ直交方向が同一 となる曲げ試験で鋼繊維混入量が $1.0 \mathrm{Vol} . \%$ の場合, 係数 $c$ は $c=0.23$ と報告されている。加えて, 文献 8）では Fig.13（b）に示す SFRC に埋設された機械式定着具を取り付けた鉄筋の引抜き実験において $c=0.23$ を用いた場合, 解析結果が実験值を過大に評価することが報 告されている。これは機械式定着具より発生する引張力作用方向 (鋼 繊維の架橋効果により引張応力を発揮する方向）と解析で使用する ひび割れ直交方向とで角度の差異が発生し, 架橋効果による引張忘 力が低減されるためであり, 下記の引張特性を低減させた方法によ り実験值を精度良く評価できることが示されている。

Fig.14 に本試験体におけるひび割れ面角度を考慮した鋼繊維架橋 効果の概念を示し, Fig.15に BJI1 試験体のパイルキャップにおける コンクリート要素の引張特性を示す。本試験体においても SFRC 引 抜き実験同様, 機械式定着具より発生する引張力によりストラット 1 に沿ってひび割れが発生するため, 上記の架橋効果による引張応 力の低減を行う。BJI1 試験体のストラット 1 は（1）式より水平面 に対し $\theta_{1}=74^{\circ}$ の角度を有している。Fig.14（a）に示すようにコンク リートのひび割れ時では, ひび割れ直交方向の引張応力度 $\left(\sigma_{t}:\right.$ Fig. 15 灰色線) が引張強度 $f_{t}$ に達した時, 引張力作用方向の応力 $\left(\sigma_{s f}\right.$ : Fig. 15 黒線）はコンクリート引張強度 $f_{t}$ の $\sin \theta_{1}$ 成分 $\left(f_{t} \cdot \sin 74^{\circ}=0.96 f_{t}\right)$ となる。

コンクリートひび割れ後は, 鋼繊維の架橋効果により引張応力を 負担すると仮定しているため, 引張力作用方向のみに $f_{t} \cdot \sin \theta_{l}$ を起 点とした引張応力 $\left(\sigma_{s f}:\right.$ Fig. 15 黒線) が $c=0.23$ で作用する。しかし, 解析で使用する引張特性はひび割れ直交方向であるため, Fig.14 (b) に示すように鋼繊維の架橋効果による引張応力 $\left(\sigma_{s f}\right)$ のさらに $\sin \theta_{1}$ 成分の低減された引張応力 $\left(\sigma_{t}:\right.$ Fig.15 灰色線) をモデル化する必 要がある。この低減された応力ーひずみ曲線はひび割れ直後に応力 が急激に低下寸るため, 出雲らのモデルでは直接モデル化できない。 そこで本解析ではこの $\sin 74^{\circ}$ 成分に低減した引張応力を簡易的にモ デル化するため, 低減した応力ーひずみ関係を精度良く評価できる 係数 $c$ について再度検討を行った。ここでは, 最大耐力時にパイル キャップに配筋した基礎梁主筋直上・直下補強筋が引張降伏してい ることから, 引張ひずみが補強筋の降伏ひずみ近傍の $\varepsilon_{t}=4800 \times 10^{-6}$ までの累積エネルギーが等価となるように係数 $c$ を検討した。その

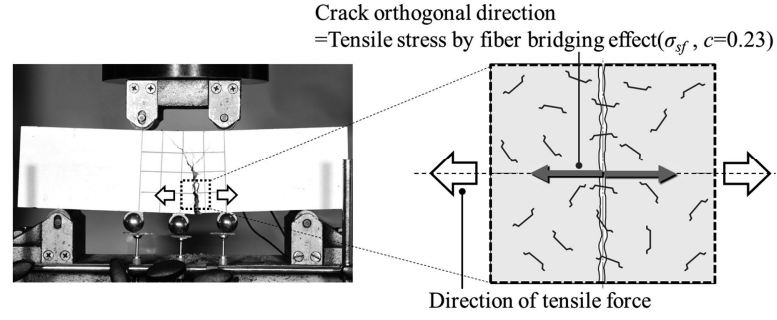

(a) SFRC bending test

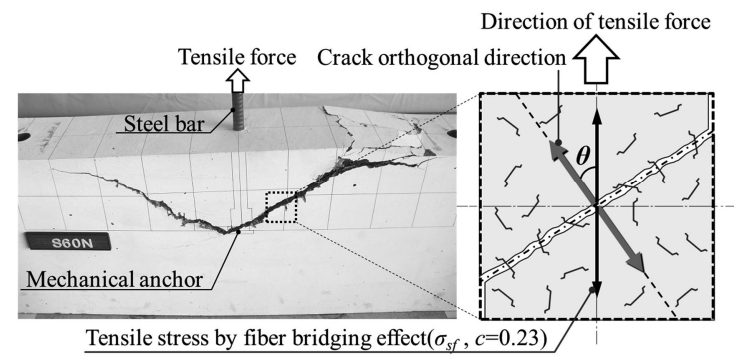

(b) SFRC pull-out test

Fig.13 Direction of tensile force and crack orthogonal direction
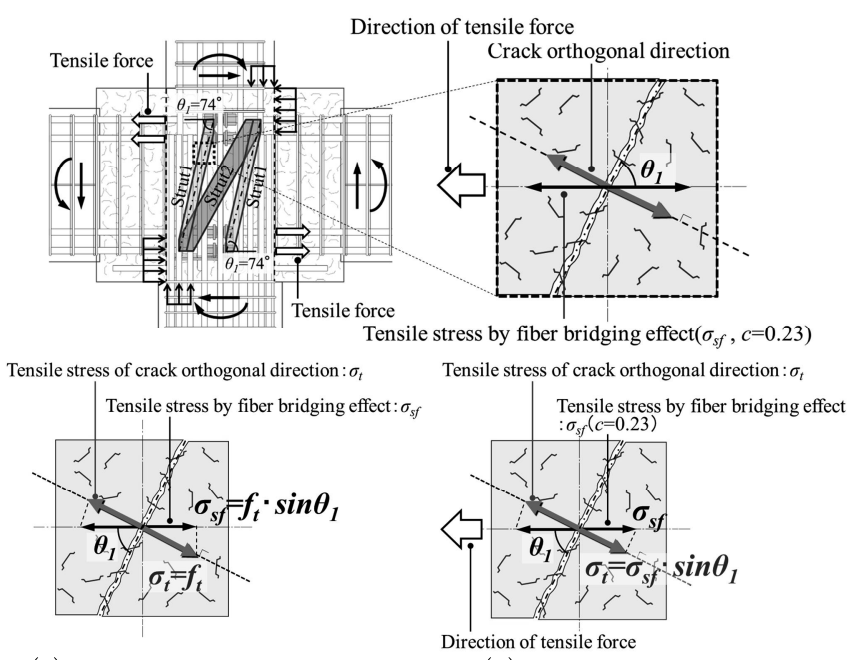

$\begin{array}{ll}\text { (a) Crack occurrence } & \text { (b) After crack }\end{array}$

Fig.14 Fiber bridging effect considering crack angle

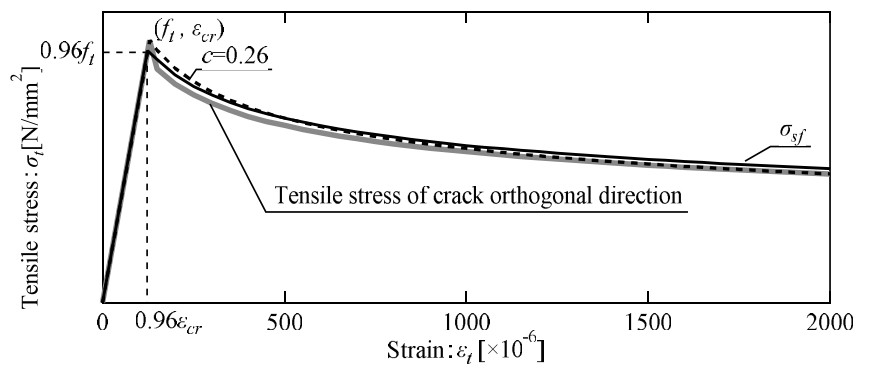

Tensile stress of crack orthogonal direction $: \sigma_{t}$

- Tensile stress by fiber bridging effect $: \sigma_{s f} \quad \ldots \ldots c=0.26$ (Izumo model) Fig.15 Calculation method of coefficient $\mathrm{c}$

結果, Fig.14に示すひび割れ面が $\theta_{l}=74^{\circ}$ の場合, $c=0.26$ (Fig.15 点線) とすることで低減した引張応力の累積エネルギーを $3.0 \%$ の精度で 精度良く評価できるため, $c=0.26$ を採用した。

またコンクリートのひび割れ後のせん断伝達モデルには

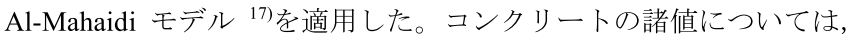
材料試験結果を用いたが, 引張強度については RC 規準 ${ }^{12)} に$ 準じて 下式より算定した。 


$$
\sigma_{c r}=0.56 \sqrt{\sigma_{B}}
$$

ここで, $\sigma_{c r}$ : コンクリート引張強度 $\left[\mathrm{N} / \mathrm{mm}^{2}\right], \sigma_{B}$ : コンクリート圧 縮強度 $\left[\mathrm{N} / \mathrm{mm}^{2}\right]$ である。

\section{(2) 鉄筋および機械式定着具モデル}

各部材の主筋およびせん断補強筋はトラス要素でモデル化した。 鉄筋の応力ーひずみ関係はバイリニアモデルとし, 履歷特性は修正 Menegotto-Pinto モデル ${ }^{18)}$ とし，材料定数は材料試験結果を用いた。 鉄筋とコンクリートとの間での付着すべりについては, 本論では完 全付着とした。

機械式定着具は 8 節点アイソパラメトリック立体要素でモデル 化し, ヤング係数 $2.05 \times 10^{5} \mathrm{~N} / \mathrm{mm}^{2}$ とした完全弾性体としてモデル化 を行った。また Fig.16に示すように機械式定着具の支圧面および小 口面寸法については，実験で使用した機械式定着具と同等の断面積 となるように要素寸法を決定し, 機械式定着具底面とコンクリート 要素の節点間に接合要素を挿入し, 両者が密着する方向には応力を 伝達し, 離間する方向には応力を伝達しないように接合要素の特性 を定義した。

\section{2 解析結果}

\section{(1) 復元力特性}

Fig.17にBJI1 試験体の解析および実験における柱せん断力一層間 変形角関係を示し，Tabel5 に各事象が発生したときの層間変形角の 実験および解析結果の比較を示す。Fig. 17 より $R=10 \times 10^{-3} \mathrm{rad}$ より小

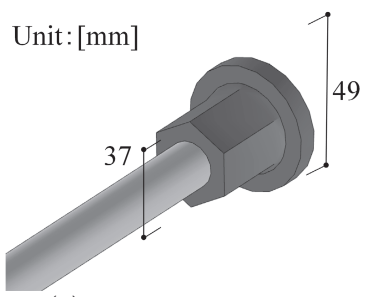

(a) Actual object

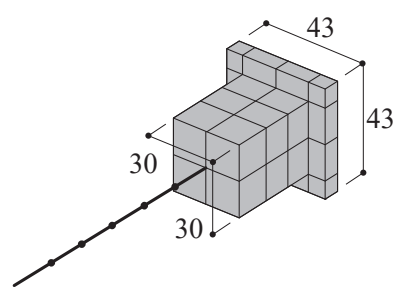

(b) Analysis model

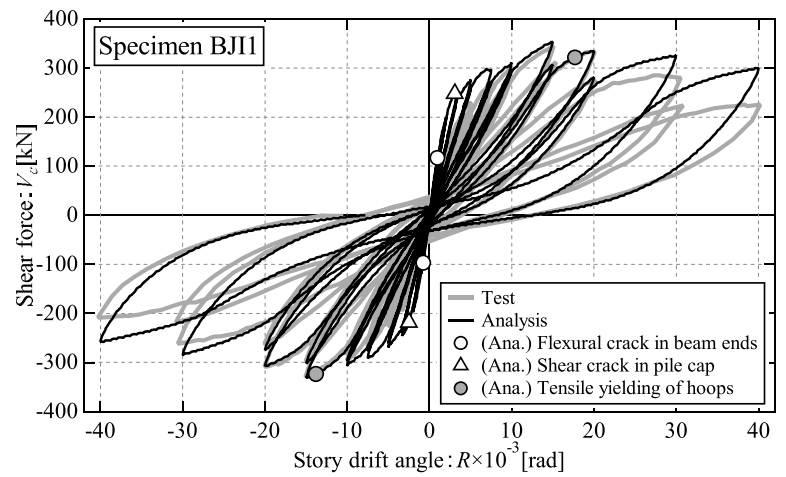

Fig.17 Shear force - story drift angle response

Table5 Major events

\begin{tabular}{|c|l|l|}
\hline Events & Test [rad] & Analysis [rad] \\
\hline $\begin{array}{c}\text { Flexural crack } \\
\text { at the beam end }\end{array}$ & $(+) R=1.0 \times 10^{-3}$ & $(+) R=1.0 \times 10^{-3}$ \\
\hline Shear crack & $(+) R=-1.0 \times 10^{-3}$ & $(-) R=-0.8 \times 10^{-3}$ \\
in pile cap & $(-) R=-2.0 \times 10^{-3}$ & $(+) R=3.1 \times 10^{-3}$ \\
\hline \multirow{2}{*}{ Yielding of hoop } & $(+) R=15.0 \times 10^{-3}$ & $(-) R=-2.5 \times 10^{-3}$ \\
& $(-) R=-10.0 \times 10^{-3}$ & $(-) R=-13.8 \times 10^{-3}$ \\
\hline \multirow{2}{*}{ Maximum strength } & $(+) R=15.0 \times 10^{-3}$ & $(+) R=15.0 \times 10^{-3}$ \\
& $(-) R=-15.0 \times 10^{-3}$ & $(-) R=-15.0 \times 10^{-3}$ \\
\hline
\end{tabular}

さい変形領域では解析による耐力が実験值に比べ大きくなる傾向を 示した。これはコンクリートの各ひび割れ荷重を解析結果が過大に 評価する傾向であり，コンクリート引張強度が実験值よりも高く設 定されていることに由来していると考えられる。しかしながら最大 耐力については $5.0 \%$ と精度良く再現できており, 最大耐力時の変 形角も再現できている。また実験結果では基礎梁主筋直上・直下補 強筋の引張降伏が発生した後, 耐力が低下したが, 本解析結果にお いても直下補強筋の引張降伏後に耐力低下が確認され破壊過程を再 現できている。また Table5 より, 各種ひび割れの発生時の層間変形 角は多少の前後はあるものの概ね再現できている。

\section{(2) 鉄筋応力}

Fig.18 およびFig.19にBJI1 試験体の解析および実験における基礎 梁主筋と基礎梁主筋直上・直下補強筋の応力推移を示す。基礎梁主 筋においては Fig.8 で示した基礎梁端部（Section A）および機械式 定着際（Section C）において比較を行った。基礎梁端部では忘力の 若干の上下はあるものの応力勾配や $R=15 \times 10^{-3} \mathrm{rad}$ 以降応力が低下す る性状を再現できている。また機械式定着際では $R=3.3 \times 10^{-3} \mathrm{rad}$ にお

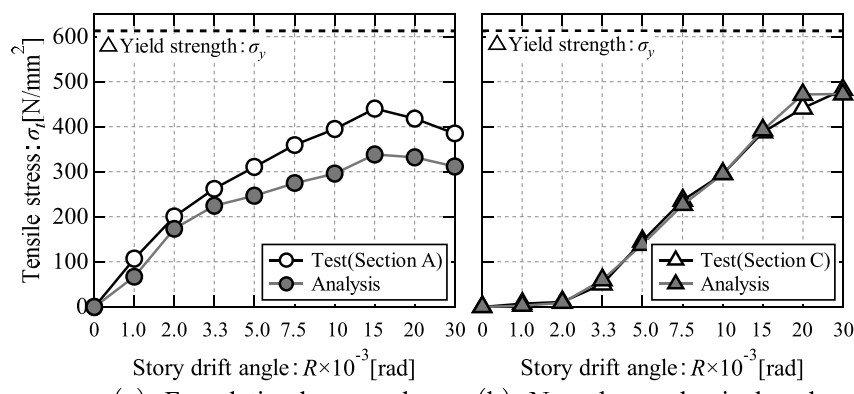

(a) Foundation beam end

(b) Near the mechanical anchor

Fig.18 Stress - story drift angle relationship of longitudinal bars

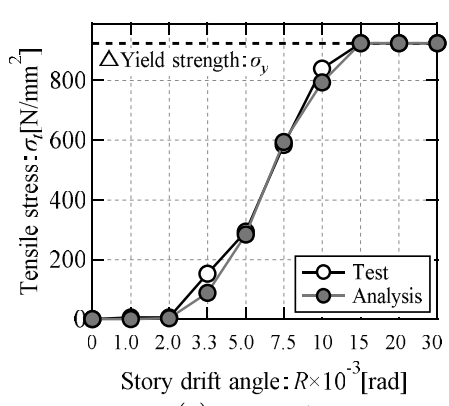

(a) Upper hoop

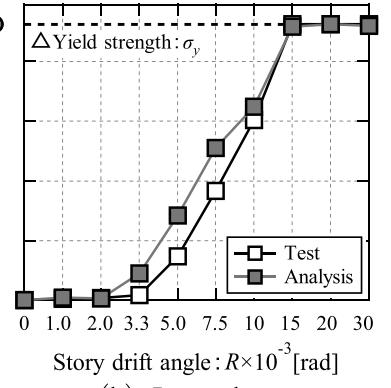

(b) Lower hoop
Fig.19 Stress - story drift angle relationship of hoops

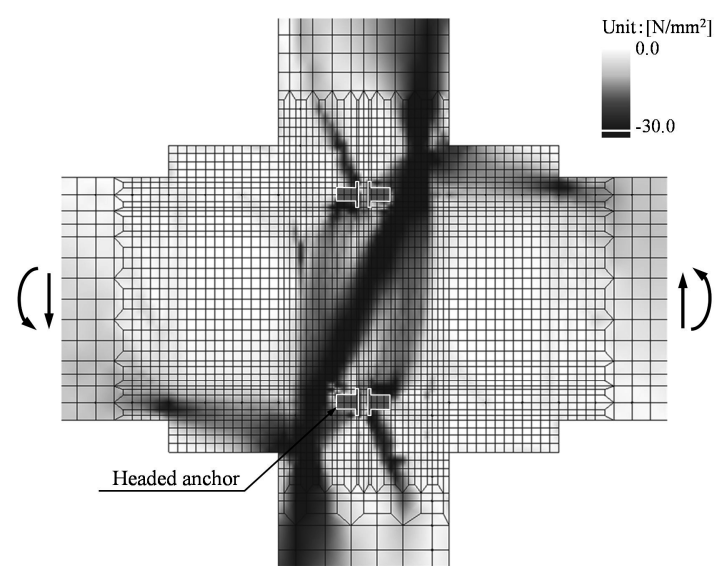

Fig.20 Distribution of minimum principal stress in symmetrical plane (BJI1) 


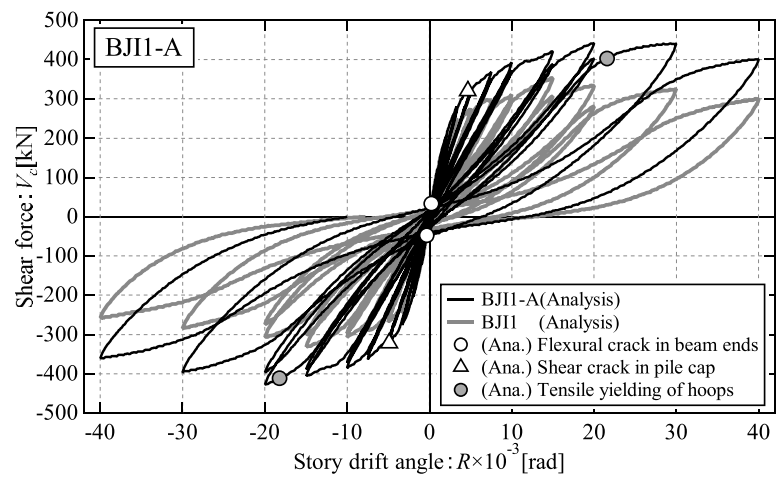

Fig.21 Shear force - story drift angle response

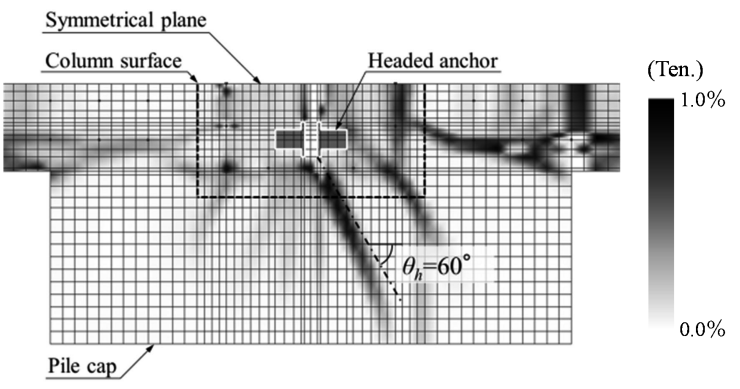

Fig.22 Distribution of maximum principal strain in horizontal plane (BJI1-A)

Table6 Ultimate strength of BJI1-A (calculated and analysis values)

\begin{tabular}{|c|c|c|c|c|c|c|c|c|}
\hline \multicolumn{3}{|c|}{ Analysis value $: Q_{\text {ana }}[\mathrm{kN}]$} & \multicolumn{3}{c|}{ Calculated value $: Q_{\text {cal }}[\mathrm{kN}]$} & \multicolumn{3}{c|}{$Q_{\text {ana(Ave. })} / Q_{\text {cal }}$} \\
\hline Positive loading & Negative loading & Average & $V_{j u}{ }^{*}{ }^{*}$ & $\begin{array}{c}Q_{T}{ }^{* 2} \\
\left(\theta_{h}=40^{\circ}\right)\end{array}$ & $\begin{array}{c}Q_{T}{ }^{* 2} \\
\left(\theta_{h}=60^{\circ}\right)\end{array}$ & $V_{j u}{ }^{{ }^{*}}{ }^{*}$ & $\begin{array}{c}Q_{T}{ }^{* 2} \\
\left(\theta_{h}=40^{\circ}\right)\end{array}$ & $\begin{array}{c}Q_{T}{ }^{* 2} \\
\left(\theta_{h}=60^{\circ}\right)\end{array}$ \\
\hline 442.1 & -427.8 & 435.0 & 417.7 & 324.2 & 513.3 & 1.04 & 1.34 & 0.85 \\
\hline
\end{tabular}

*1 Calculated ultimate shear strength in joint based on formula (1)

*2 Calculated anchorage failure strength in joint based on formula (9)

*3 Calculated ultimate flexural strength based on AIJ formula

いて応力が増加する傾向やその後の応力勾配を再現できている。ま た基礎梁主筋直上・直下補強筋については, 応力発現時の変形角や 応力勾配, さらに引張降伏時の変形角を再現できている。

\section{(3) 最小主応力分布}

Fig.20にBJI1 試験体の最大耐力を記録した $R=15 \times 10^{-3} \mathrm{rad}$ 時の奥行 き方向の $1 / 2$ 対称面（Fig.12（a） における最小主応力分布を示す。 Fig.20よりパイルキャップの上端, 下端, 柱面および杭面で囲われ た領域（Fig.5 赤点線内）の圧縮縁を結ぶ対角線上の圧縮ストラット と, 引張側基礎梁主筋に取りついた機械式定着具と圧縮縁を結ぶ圧 縮ストラットの 2 つストラットが形成されていることが確認され， 基礎架構においても筆者らが提案する分割ストラットモデルにより 応力を伝達していることが確認された。

\section{3 掻き出し定着破壊時の有効幅}

3 章で示した BJI1 試験体はパイルキャップでの破壊を誘発させる ため, パイルキャップの幅を $420 \mathrm{~mm}$ まで減少させ平面的に細長の 長方形としたが，一般的にはパイルキャップは平面的に正方形とす ることが多い。そこで, パイルキャップ幅を $800 \mathrm{~mm}$ まで増加させ 平面的に正方形とした場合の応力伝達機構および終局耐力の評価に ついて解析モデル BJI1-A を作成し検討を行った。解析モデルは 4.1 節で述べた材料構成則および境界条件を用い, パイルキャップ幅が $800 \mathrm{~mm}$ となるようにコンクリート要素のみを増加させた。

Fig.21 に解析モデル BJI1-A の柱せん断力-層間変形角関係を示す。 Fig.21 より, パイルキャップ幅を増加させた場合, 最大耐力が $R=20 \times 10^{-3} \mathrm{rad}$ で発揮され, 最大耐力は BJI1 試験体の実験值と比較し て $1.28 〜 1.30$ 倍増加した。また解析モデル BJI1-A においても $R=20 \times 10^{-3} \mathrm{rad}$ 付近で直上および直下補強筋の引張降伏が発生した後, 緩やかに耐力が低下した。なお，解析終了時まで柱・杭および基䃈 梁主筋の引張降伏は発生しなかった。

Fig.22 に解析モデル BJI1-A の基礎梁上端 2 段筋位置の水平断面に おける最大主ひずみ（引張ひずみ）分布を示す。（9）式の掻き出し 定着耐力算定時に使用寸る有効幅 $b_{e}$ について, 勒性保証型耐震設計 指針 ${ }^{11)}$ では梁主筋の定着長さの 0.8 倍を上限として $C_{e l}$ および $C_{e 2}$ を
求めている。これは文献 19) よりプレーンコンクリートに $90^{\circ}$ 折曲 げ定着された鉄筋から発生する水平破壊面を $\theta_{h}=40^{\circ}$ として定めら れたものである。一方 Fig. 22 では, 機械式定着具を起点として水平 面に $\theta_{h}=60^{\circ}$ に沿った方向に引張ひずみが発生しており, SFRC 内で 機械式定着された接合部では文献 19）と比較して水平破壊面の角度 が増加する傾向を確認した。

Table6 に解析モデル BJI1-A の接合部せん断強度および掻き出し 定着耐力の計算值および解析值の比較を行う。掻き出し定着耐力計 算值には水平破壊面角度を $\theta_{h}=40^{\circ}$ および $\theta_{h}=60^{\circ}$ の場合をそれぞれ 示す。Table6 より水平破壊面を $\theta_{h}=40^{\circ}$ とした場合, 耐力計算值は 掻き出し定着耐力で最大耐力が決定されるが，パイルキャップ幅の 増加による耐力上昇を再現できておらず，かつ解析值を過小評価す る傾向を示した。一方, 水平破壊面を $\theta_{h}=60^{\circ}$ とした場合では, 耐 力計算值は分割ストラットモデルによるせん断強度で最大耐力が決 定され, 解析での平均值を 1.04 倍で精度良く評価できた。さらにパ イルキャップ幅の増加による耐力上昇も再現できている。以上のこ とから, 接合部内で機械式定着された SFRC 接合部では择き出し定 着破壊時の水平破壊面は $\theta_{h}=60^{\circ}$ 程度であると考えられ, パイルキャ ップのせん断耐力は分割ストラットモデルに基づく接合部せん断強 度と, 水平破壞面を $\theta_{h}=60^{\circ}$ とした場合の搔き出し定着耐力のどち らか小さい方で決定することを確認した。

\section{5. まとめ}

本論では基礎梁主筋をパイルキャップ内で機械式定着した SFRC 基礎架構について, 構造実験および 3 次元非線形 FEM 解析を実施 し, 以下の知見を得た。

1）本研究で提案したパイルキャップでは，パイルキャップの上端, 下端, 柱面および杭面で囲われた範囲を接合部パネルとして応 力伝達機構を形成する。

2）接合部パネル内において左右の基礎梁端部圧縮縁を結ぶストラ ットと, 引張側基礎梁主筋に取りついた機械式定着具から発生 する 2 つのストラットが形成される分割ストラットモデルによ 
り応力を伝達していることを確認した。

3）非線形 3 次元 FEM 解析より, SFRC パイルキャップ内で機械式 定着された基礎梁主筋の择き出し定着破壊時の水平破壊面は $\theta_{h}=60^{\circ}$ 程度であると推察される。

4）本構法を用いたパイルキャップのせん断耐力は, 分割ストラッ トモデルに基づく接合部せん断強度と，柱面および杭面からの 主筋の定着長を用い, 水平破壊面を $\theta_{h}=60^{\circ}$ とした場合の掻き出 し定着耐力のどちらか小さい方で決定する。

\section{謝辞}

実験にあたり材料の提供を朝日工業株式会社およびベカルトジャ パン株式会社より受けた。ここに記し，謝意を示す。

\section{参考文献}

1) Y.Tsuboi and M.Tomii : Tanki ouryoku wo taishoutosuru harihashira setsugoubu ni okeru harishukin no haikinhou to suiheihanchi no kouka ni kansuru jikkenteki kenkyuu (part1), Proceeding of the Architectural Research Meetings, Kanto Chapter, Architectural Institute of Japan, No.21, pp.230-235, 1953.3 (in Japanese)

坪井善勝, 冨井政英 : 短期應力を対照とする梁柱接合部に於ける梁主筋 の配筋法と水平ハンチの効果に関する実験的研究（その 1），日本建築 學會関東支部研究報告集, 第 21 巻, pp.230-235, 1953.3

2) Paulay,T., R.Park and M.J.N.Priestly : Reinforced Concrete Beam-Column Joints Under Seismic Actions, ACI Journal, Vol.75, No.11, pp.585-593, 1987.11

3) Architectural Institute of Japan : Design Guidelines for Earthquake Resistant Reinforced Concrete Buildings Based on Ultimate Strength Concept, 1990 (in Japanese)

日本建築学会 : 鉄筋コンクリート造建物の終局強度型耐震設計指針・同 解説, 1990

4) H.Shiohara : Reinforced concrete beam-column joint : Failure mechanism overlooked, Journal of Structural and Construction Engineering(Transactions of AIJ), Vol.73, No.631, pp.1641-1648，2008.9 (in Japanese) 塩原等: 鉄筋コンクリート柱梁接合部, 見逃された破壊機構, 日本建築 学会構造系論文集, 第 73 巻, 第 631 号, pp.1641-1648, 2008.9

5) H.Kondo, H.Yamazaki, Y.Goto and K.Nishimura : Study on failure of R/C Sub-assemblages of Exterior Column-Pile and Foundation Beam with Multi-layer Arranged Reinforcing Bars(Part1 Part2), Summary of Technical Papers of Annual Meeting, Architectural Institute of Japan, C-2, structureIV, pp.699-702, 2013.8(in Japanese) 近藤晴紀, 山崎寛悦, 後藤康明, 西村康志郎 : 多段配筋された $\mathrm{RC}$ 基礎 梁-外柱・杭接合部の破壊性状に関する研究（その 1〜その 2), 日本建 築学会大会学術講演梗概集, C-2, 構造IV, pp.699-702, 2013.8

6) Z.Tomiyama, T.Owaku, Y.Uesaka, S.Kishida and S.Hayashi : Experimental Study on Seismic Performance of Pile caps on the Exterior frame (No.1 No.2), Summary of Technical Papers of Annual Meeting, Architectural Institute of Japan, C-2, structureIV, pp.695-698, 2013.8 (in Japanese) 冨山善太，大和久貴義，上坂宜嗣，岸田慎司，林静雄：卜形部分架構を 有するパイルキャップの耐震性能に関する実験研究（その 1〜その 2）, 日本建築学会大会学術講演梗概集, C-2, 構造IV, pp.695-698, 2013.8
7) Y.Ishikawa : Steel Fibre Reinforced Concrete Interior Beam-Column Joints with Headed Anchor of Beam Longitudinal Bars, Journal of Structural Engineering, Vol.62B, pp.121-132, 2016.4 (in Japanese) 石川裕次 : 梁主筋を接合部内で機械式定着した SFRFC 十字形接合部，構 造工学論文集, Vol.62B, pp.121-132, 2016.4

8) S.Kake and Y.Ishikawa : Stress Transfer Mechanism in Steel Fiber Reinforced Concrete Interior Beam-Column Joints with Beam Longitudinal Headed Steel Bars under Lateral Loading, Concrete Research and Technology, Vol.28, pp.79-91，2017.9 (in Japanese)

掛悟史，石川裕次：梁主筋を接合部内で機械式定着した SFRC 十字形接 合部における応力伝達機構, コンクリート工学論文集, 第 28 巻, pp.79-91, 2017.9

9) Architectural Institute of Japan : Recommendations for Design of Building Foundations, 2001 (in Japanese) 日本建築学会 : 建築基礎構造設計指針, 2001

10) Y.Kawasaki : The process of validation for simulation models using optical 3D measurement techniques by DIC, and case studies, Proceedings of the Conference on Computational Engineering and Science, Vol.18, 2013.6 (in Japanese)

川崎雄介 : DIC による光学式 3 次元計測技術を用いた妥当性確認手法と その事例，計算工学講演会論文集，Vol.18，2013.6

11) Architectural Institute of Japan : Design Guidelines for Earthquake Resistan Reinforced Concrete Buildings Based on Inelastic Displacement Concept, 1999 (in Japanese)

日本建築学会 : 鉄筋コンクリート造建物の鞆性保証型耐震設計指針・同 指針, 1999

12) Architectural Institute of Japan : AIJ Standard for Structural Calculation of Reinforced Concrete Structures, 2010 (in Japanese)

日本建築学会 : 鉄筋コンクリート構造計算規準・同解説, 2010

13) Noguchi,H. et al. : TTC Hsu Symposium, ACI, SP-265, pp.223-244, 2009

14) Saenz, L.P. : J.Am.Concr.Inst., Vol.61, pp.1229-1235, 1964

15) Kent,D.C. and Park R. : J.Struct.Div., ASCE, ST7, pp.1969-1990, 1971

16) J.Izumo, H.Shima and H.Okamura : Mennairyoku wo ukeru tekkinkonkurito ita youso no kaiseki moderu, Concrete Research and Technology, No.87.9-1, pp.107-120, 1987.9 (in Japanese)

出雲淳一，島弘，岡村甫：面内力を受ける鉄筋コンクリート板要素の解 析モデル，コンクリート工学論文集，No.87.9-1，pp.107-120, 1987.9

17) Al-Mahaidi. R.S.H. : Nonlinear Finite Element Analysis of Reinforced Concrete Deep Members, Report79-1, Dep.of Structural Engineering, Cornell Univ., 1979.1

18) Ciampi,V, et al. : Analytical Model for Concrete Anchorages of Reinforcing Bars Under Generalized Excitations, Report No.UCB/EERC-82/23, Univ. of California, Berkeley, 1982.11

19) O.Joh, Y.Goto, A.Kitano and Y.Miyamoto : Influence of Axial Stress and Cover Concrete Thickness on 90-degree Anchorage Strength in Beam-column Joint, Proceedings of Japan Concrete Institute, Vol.25, No.2, pp.321-326,1995 (in Japanese)

城攻，後藤康明，北野敦則，宮本泰志：柱梁接合部内 $90^{\circ}$ 折曲げ筋の定着 耐力に及ぼす柱軸力・側方被り厚等の影響, コンクリート工学年次論文 集, Vol.17, No.2, pp.321-326, 1995 


\title{
SEISMIC PERFORMANCE OF A STEEL FIBER REINFORCED CONCRETE PILE CAP USING HEADED MAIN BARS IN FOUNDATION BEAMS
}

\author{
Satoshi KAKE ${ }^{* 1}$, Masanori SAKATA*1, Masaki TABEI*1, \\ Masahiro HOSHINO ${ }^{* 1}$, Yoshihiro OHTA*2 and Yuji ISHIKAWA*3 \\ ${ }^{* 1}$ Building Design Dept., Tokyo Main Office, Takenaka Corporation \\ ${ }^{* 2}$ General Manager, Structural Engineering Dept., Research \& Development Institute, Takenaka Corporation, Dr.Eng. \\ ${ }^{* 3}$ Prof., Shibaura Institute of Technology, Dr.Eng.
}

In this study, the seismic performance of a steel fiber reinforced concrete (SFRC) pile cap using headed bars as main reinforcement in its foundation beams was examined by a lateral loading test and a non-linear 3-dimentional FEM analysis.

In order to investigate the ultimate shear strength of the SFRC pile cap, a specimen designed to ensure a shear failure of its pile cap was prepared and tested under a lateral loading. The study showed that the critical region of the foundation beam would develop within the pile cap where shear cracks concentrated (area limited by the opposite sides of the column and pile faces).

Whereas the first main shear crack formed along the diagonal line connecting the compressive parts at the opposite beam end sections, the other crack formed along the line connecting the compressive part at the foundation beam end section to the head anchors of the foundation beam longitudinal bars of the same beam end side.

Also, in order to investigate the stress transfer mechanism of the pile cap when subjected to a lateral loading, a non-linear 3-dimensional FEM analysis was carried out, considering the Izumo model to define the tensile properties of SFRC. The analysis could accurately reproduce the experimental results, in terms of the shear force - story drift angle relationship, and stress - story drift angle relationship of the reinforcement.

Also, a double strut model, involving the development of two struts in the pile cap, was identified as the stress transfer mechanism under lateral loading. The first strut to be formed connects the compressive parts at the opposite foundation beams end sections. The other strut to be formed connects the compressive part at the foundation bema end section to the head anchors of the foundation beam longitudinal bars of the same beam end side.

An FEM analytical model, similar to the tested specimen, but with a square planar shape pile cap was also investigated. The analytical results showed that the deviation of the horizontal failure surface was about $\theta_{h}=60^{\circ}$ from the headed bar axis. In addition, the ultimate shear strength of the pile cap sub-assemblage was determined by considering the lesser of the double strut model strength and the anchors pull-out strength when the horizontal failure surface is $\theta_{h}=60^{\circ}$. 